\title{
REVIEW BUKU SYARAH KONSTITUSI UUD 1945 DALAM PERSPEKTIF ISLAM
}

\author{
Novita Siswayanti \\ Puslitbang Lektur dan Khazanah Keagamaan Badan Litbang dan \\ Diklat Kemenag RI Jl. M.H. Thamrin No. 6 Lantai 18 Jakarta \\ e-mail: iieta_1717@yahoo.com
}

Masdar Farid Mas'udi, Sejarah Konstitusi UUD 1945 dalam Perspektif Islam, Ahmad Baedowi (ed.), Proofreader Muhammad Husnil; (Cet. ke-2; Jakarta: Pustaka Alvabet bekerjasama dengan Lembaga Kajian Islam dan Perdamaian (LaKIP), 2010), $236 \mathrm{hlm}, 13 \times 20 \mathrm{~cm}$.

IDENTITAS PENULIS. Masdar Farid Mas'udi lahir pada 1954 di Purwokerto. Ia belajar agama Islam dari Kyai Chudlori (alm.) di Pesantren Tegalrejo, Magelang (1966-1968), Kyai Ali Maksoem (alm.) di Pesantren Krapyak, Yogyakarta (19681974), dan di Fakultas Syariah IAIN Sunan Kalijaga, Yogyakarta (1972-1979 ). Ia juga belajar filsafat pada Program Pascasarjana UI (1994-1996). Di lingkungan kaum Nahdliyin, Kyai Masdar termasuk sosok berpengaruh. Ia pernah menjabat Wakil Ketua Tim Asistensi Pemikiran Keagamaan untuk Rais Am dan Ketua Umum PBNU (1984-1994), Katib I Syuriah PBNU (1999-2004), Pelaksana Harian Ketua Umum PBNU (2004), dan Ketua PBNU (2005-2010). Setelah Muktamar ke-32 PBNU, kini ia dipercaya menjabat Rais Syuriah PBNU (2010-2015). Kiprahnya di dunia profesional tak kalah hebat. Berbagai posisi penting pun ia jabat, antara lain anggota Komisi Ombudsman Nasional (2001-2009), anggota Komisi Ombudsman Harian KOMPAS (2000-2004), anggota Dewan Etik ICW (2004-2009), Direktur P3M (2000-2009), anggota Panel-45 Presiden RI untuk Sidang Umum PBB 2005, dan anggota Delegasi Indonesia untuk Konferensi PBB tentang HAM di Jenewa (Maret, 2008). Pemikiran Kyai Masdar termaktub dalam sejumlah buku, yakni Agama Keadilan: Risalah Zakat [Pajak] dalam Islam (1993) serta Islam dan Hak-Hak Reproduksi Perempuan (1997). Selain itu, ia kerap pula menuangkan gagasannya dalam banyak artikel di berbagai koran dan majalah serta makalah untuk beragam seminar di dalam negeri maupun di luar negeri. 


\section{PENDAHULUAN}

Indonesia adalah negara konstitusional yang ber-Ketuhanan Yang Maha Esa yang melindungi setiap pemeluk agama untuk melaksanakan ajaran agamanya masing-masing. Indonesia adalah religious nation state yakni sebuah negara kebangsaan yang religious yang melindungi dan memfasilitasi berkembangnya semua agama yang dipeluk oleh rakyatnya untuk beribadah sesuai dengan keyakinannya masing-masing. Indonesia menjadi kan agama sebagai ruh atau substansi undang-undang yang sarat dengan etika dan moralitas di dalam penyelenggaraan negara.

Dalam hubungannya dengan konstitusi sebagai hukum tertinggi suatu negara (supreme law of the land) yang merupakan pondasi dasar dalam sistem ketatanegaraan suatu negara. ${ }^{1}$ UUD 1945 dan Pancasila sebagai hukum nasional harus menjamin keutuhan ideologi dan integrasi wilayah negara, serta membangun toleransi beragama yang berkeadilan dan berkeadaban. Sehingga dalam penataan hubungan antara agama dan negara harus dibangun atas dasar simbiosis mutualisme di mana yang satu dan yang lain saling melengkapi.

Namun, tampaknya banyak pihak yang kemudian lupa bahwa Negara Kesatuan Republik Indonesia sejatinya dilahirkan dari semangat kebhinnekaan. Dan bahkan masih ada sebagian masyarakat yang merasa teralienasi dari UUD 1945, lantas mengembangkan mentalitas "luar pagar" yang memandang konstitusi tersebut semata-mata sebagai produk 'sekuler' yang tercerabut dari nilai-nilai keagamaan.

Terlebih lagi, pada saat ini tengah bermunculan wacana dan gerakan untuk memperjuangkan kembali "formalisasi" hukum Islam, misalnya dengan memberlakukan piagam Jakarta. Hal ini terjadi saat reformasi 1998 sampai Agustus 2002, gerakan politik

${ }^{1}$ Jimly Asshiddiqie, Membangun Budaya Sadar Berkonstitusi, Makalah diseminarkan di DPP Partai Golkar, Jakarta: 8 Juli 2008 
resmi di DPR/MPR menghendaki agar Indonesia menjadi negara Islam dengan menjadikan piagam Jakarta sebagai dasar negara. Ada juga kelompok haluan kiri yang ingin menjadikan Indonesia sebagai negara sekuler bahkan berideologi marxisme.

Sementara itu ada juga kelompok ekstrim kanan yang ingin mengganti Pancasila dengan 'asas Islam' dengan sistem pemerintahan khalifah. Pada tahun 2006, ada tiga gerakan yang menginginkan syariat Islam yaitu Hisbut Tahrir Indonesia (HTI), Majelis Mujahidin Indonesia (MMI) dan Komite Persiapan Pemberlakuan Syariat Islam (KPPSI) Sulawesi Selatan. ${ }^{2}$

Oleh karena itu untuk menghadirkan suatu kancah permainan (playing field) yang fair bagi kemajemukan kepentingan, semua warga harus taat asas pada consensus dasar, yakni konstitusi. Konstitusi dalam konteks negara modern yang majemuk selalu dimuati nilai-nilai luhur yang bersifat universal dan hal-hal dasar yang bisa disepakati bersama oleh segenap komponen warga yang bersangkutan, meskipun masing-masing punya latar belakang agama, keyakinan maupun budaya berbeda-beda.

Tidak ada negara modern yang majemuk yang konstitusinya secara langsung merujuk pada bunyi kitab suci agama tertentu. Pola ini secara gamblang telah diteladankan oleh Nabi Muhammad SAW, sebagai tokoh utama pembentuk negara Madinah yang modern dan majemuk. Nabi SAW pada saat itu tidak punya pretensi sedikitpun untuk menjadikan Al-Qur'an sebagai Konstitusi Madinah. Konstitusi Negara Madinah adalah hasil negosiasi dan kesepakatan semua komponen masyarakat yang diperlakukan sama, meskipun memiliki latar belakang agama beragam. (h. 5)

Demikian pula dalam UUD 1945, secara yuridis konstitusional memproteksi hak warga negara mengenai kebebasan bagi pemeluk agama untuk menjalankan kewajibannya.

${ }^{2}$ Al Halaj Muhyiddin, Pancasila dan Pembukaan UUD 1945 Tidak Bisa Diubah dan Tidak Boleh Diubah, al-Kautsar-Dhibradotkom, 2010 
Pada Pasal 29 ayat (1) UUD 1945 disebutkan bahwa "Negara berdasar atas Ketuhanan Yang Maha Esa" dan ayat (2) "Negara menjamin kemerdekaan tiap-tiap penduduk untuk memeluk agamanya masing-masing dan untuk beribadah menurut agama dan kepercayaannya itu."

Dalam implementasinya konstitusi UUD 1945 pasal 29 di atas memberikan kesimpulan bahwa UUD 1945 mempunyai nilai keislaman yang tinggi yang berhubungan dengan keyakinan dalam kehidupan berbangsa dan bernegara di Indonesia. Di sanping itu dalam demokrasi konstitusional yang dianut Indonesia, kebebasan untuk beragama dan berkeyakinan (freedom of religion) diakui dan dijamin kukuh sebagai hak asasi manusia, termasuk didalamnya hak untuk beribadah (to manifest religion). Nilai-nilai agama yang luhur dan universal menjiwai segenap prikehidupan bernegara tanpa terjebak dalam formalisasi agama.

Bagi masyarakat muslim, kesetiaan terhadap konstitusi tersebut memerlukan usaha untuk mengakhiri mentalitas "luar pagar". Dengan cara menemukan kesesuaian antara nilai-nilai substantif keislaman dan nilai-nilai dasar konstitusi. Kaum muslim diharapkan mampu mewujudkan diri dalam sikap hidup kebangsaan yang tidak lagi melihat kesenjangan antara keislaman dan keindonesiaan. Sebagai pendukung dan sumber utama nilainilai keindonesiaan, Islam diharapkan tampil dengan tawarantawaran kultural yang produktif dan konstruktif, khususnya dalam pengisian nilai-nilai keindonesiaan dalam kerangka Pancasila dan Undang-Undang Dasar 1945.

Sebagai suatu upaya untuk memaparkan harmonisasi kesesuaian antara nilai dasar konstitusi (UUD 1945) dengan nilainilai keislaman, maka buku berjudul Syarah Konstitusi UUD 1945 dalam Perspektif Islam menarik untuk dikaji dan ditelaah. Buku ini akan menunjukkan bahwa nilai-nilai dan aturan dasar konstitusi UUD 1945 tidaklah bertentangan, melainkan justru sejalan dengan substansi nilai keislaman. 


\section{SEPUTAR ISI BUKU}

Buku berjudul Syarah Konstitusi UUD 1945 ini ditulis oleh Masdar F. Mas'udi bergaya bahasa ajakan/seruan kepada pembaca khususnya kaum muslim. Dengan metode ceramah penulis menguraikan pointers dari ide pokok tiap bab atau pasal UUD 1945 yang dianggap penting. Penulis memberikan rujukan dalildalil naqliyah maupun dalil-dalil aqliyah dari tiap pointers yang disyarah. Penulis ingin menunjukkan kepada pembaca bahwa kandungan konstitusi UUD 1945 adalah islami dan sejalan dengan ajaran Islam. Indonesia dengan dengan dasar Pancasila dan UUD 1945 adalah negara yang islami, tapi bukan negara Islam. Negara Islami adalah negara yang secara resmi tidak menggunakan nama dan simbol-simbol Islam tetapi substansinya mengandung nilainilai substantif ajaran Islam.

Buku ini diterbitkan atas kerjasama antara Lembaga Kajian Islam dan Perdamaian (laKIP) dengan Alvabet. Buku ini disusun atas prakarsa dan dukungan Prof. Dr. Jimly Ashiddiqie, SH., selaku pakar konstitusi maupun Ketua Mahkamah Konstitusi Republik Indonesia (periode 2003-2008). Kehadiran buku ini mendapat sambutan dari berbagai pihak, khususnya Mahkamah Konstitusi. Buku ini diterbitkan sebagai bagian keikutsertaan Mahkamah Konstitusi dalam mendorong pembumian konstitusi di tengah masyarakat.

Janedjri M. Gaffar sebagai Sekjen Mahkamah Konstitusi dalam prakatanya menuliskan harapan bahwa buku ini nantinya dapat menumbuhkan sadar konstitusi bagi masyarakat, khususnya kaum muslim bahwa sesungguhnya terdapat kesesuaian antara nilai-nilai konstitusi dengan nilai-nilai keislaman. Selain itu cita-cita nasional pun sejalan dengan nilai-nilai luhur agama. (h. xi)

Buku ini secara utuh berisi naskah konsolidasi dalam satu naskah yang diterbitkan Sekretariat Jenderal MPR-RI. Naskah resmi Undang-Undang Dasar Negara Republik Indonesia Tahun 
1945 adalah naskah asli yang diundangkan dalam Lembaran Negara Tahun 1959 No. 75, meliputi Pembukaan, Batang Tubuh dan Penjelasannya, beserta Perubahan Pertama UUD 1945, Perubahan Kedua UUD 1945, Perubahan Ketiga UUD 1945, Perubahan Keempat UUD 1945. (h. xxxi)

Adapun secara terperinci bagian-bagian yang tertulis dari buku ini adalah: Prakata pensyarah; Prakata Sekjen Mahkamah Konstitusi; Pengantar Prof. Dr. Moh. Mahfud MD, SH.; Pengantar Prof. Dr. Jimly Asshiddiqie, SH.; Sambutan KH. M.A. Sahal Mahfudh; Pembukaan (Preambule); Bab I Bentuk dan Kedaulatan; Bab II Majelis Permusyawaratan Rakyat; Bab III Kekuasaan Pemerintahan Negara; Bab IV Dewan Pertimbangan Agung; Bab V Kementerian Negara; Bab VI Pemerintahan Daerah; Bab VII Dewan Perwakilan Rakyat; Bab VIIA Dewan Perwakilan Daerah; Bab VIIB Pemilihan Umum; Bab VIII Hal Keuangan; Bab VIIIA Badan Pemeriksa Keuangan; Bab IX Kekuasaan Kehakiman; Bab IXA Wilayah Negara; Bab X Warga Negara dan Penduduk; Bab XA Hak Asasi Manusia; Bab XI Agama; Bab XII Pertahanan dan Keamanan Agama; Bab XIII Pendidikan dan Kebudayaan; Bab XIV Perekonomian Nasional dan Kesejahteraan Sosial; Bab XV Bendera, Bahasa, dan Lambang Negara serta Lagu Kebangsaan; Bab XVI Perubahan Undang-Undang Dasar; Indeks; Indeks kata-kata kunci yang disyarahi.

Namun demikian tidak semua bab dari perundang-undangan pada buku ini disyarahkan. Adapun bab-bab yang tidak disyarahkan adalah: Bab IV Dewan Pertimbangan Agung; Bab V Kementerian Negara; Bab VI Pemerintahan Daerah; Bab VIIA Dewan Perwakilan Daerah; Bab VIIIA Badan Pemeriksa Keuangan; Bab IXA Wilayah Negara; Bab X Warga Negara dan Penduduk; Bab XV Bendera, Bahasa, dan Lambang Negara serta Lagu Kebangsaan; Bab XVI Perubahan Undang-Undang Dasar.

Dalam buku ini uraian syarah ditulis utuh tidak per-ayat, tetapi per-gagasan, boleh jadi per-pasal ataupun per-bab. Terlebih 
dahulu rumusan bab atau pasal yang akan disyarah diberi kode. Setelah itu masing-masing gagasan pokok pada tiap bab atau pasal yang diberi kode diuraikan dalam tema tersendiri. Syarah dalam buku ini hanya diberikan terhadap materi-materi atau gagasan pokok secara garis besar dengan maksud untuk mengajak pembaca memahami konsep-konsep kenegaraan yang terkandung didalamnya dengan menggunakan perspektif ajaran Islam.

Di samping itu juga syarah dalam buku ini dimaksudkan untuk mencari persesuaian antara nilai-nilai agama yang agung dan suci yang ada dalam Islam dikomparasikan dengan kearifan dan kebijakan lokal yang menjadi ciri khas bangsa Indonesia yang terangkum dalam Pancasila dan UUD 1945. Khususnya prinsip ketuhanan yang ditanamkan dalam UUD 1945 oleh Founding Fathers merupakan suatu perwujudan akan pengakuan keagamaan. Dalam perspektif Islam, hal ini memberikan pengakuan terhadap eksistensi Islam sebagai agama resmi negara sekaligus sebagai hukum yang berlaku di Indonesia.

Pada buku ini hal pokok dan mendasar yang disyarahi adalah naskah UUD 1945 khususnya bagian pembukaan (preambule). Bagian tersebut dianggap menginspirasi dan menjiwai keseluruhan pasal demi pasal atau bab demi bab dari naskah UUD 1945 yang termaktub dalam Batang Tubuh. Pembukaan UUD 1945 terdiri dari empat alinea yang merupakan "basic belief" atau "way of life" atau kerangka berpikir dan bertindak dari bangsa Indonesia secara keseluruhan sebagai suatu sarana atau kerangka kesatuan gerak dalam mencapai visi dan misi bangsa. Pembukaan UUD 1945 menjadi landasan hukum atau payung hukum adanya Batang Tubuh UUD 1945.

Adapun tema/kerangka berpikir dari keempat alinea Pembukaan UUD 1945 yang dituliskan dalam buku ini berisikan tentang: pertama perihal mutlaknya kemerdekaan dan kebebasan bagi manusia sebagai pemikul tanggung jawab kekhalifan Allah di muka bumi; kedua perihal tujuan berdirinya Negara Kesatuan 
Republik Indonesia yang merdeka, berdaulat, adil, dan makmur; ketiga perihal semangat keimanan kepada Tuhan Yang Maha Esa sebagai landasan spiritual-moral seluruh gerak dan perjuangan bangsa dalam membangun Negara; keempat perihal lima prinsip dasar bagi kehidupan bermasyarakat, berbangsa, dan bernegara Indonesia yang hendak dibangun. (h.5)

Di samping itu dalam buku ini disyarahkan juga lima asas dasar negara, yaitu Pancasila. Rumusan Pancasila sebagaimana tertuang dalam alinea keempat UUD 1945 merupakan refleksi dari falsafah dan budaya bangsa, termasuk di dalamnya bersumber dan terinspirasi dari nilai-nilai dan ajaran agama yang dianut bangsa Indonesia. Syarah pada lima asas dasar negara ini akan menguraikan nilai-nilai yang terdapat pada masing-masing sila dan relasinya dengan nilai-nilai ajaran agama, khususnya Islam. Adapun secara terperinci lima prinsip dasar bagi kehidupan negara Indonesia yang disyarahkan dalam buku ini, yaitu:

Pertama, Ketuhanan Yang Maha Esa sebagai landasan spiritual yang direflesikan dalam Bab XI tentang agama. Dalam hal ini dapat dibuktikan bahwa UUD 1945 sejalan dengan nilai keislaman yang tinggi berhubungan dengan keyakinan dalam kehidupan berbangsa dan bernegara. Negara Indonesia mengakui dan meyakini akan keberadaan Tuhan yang menciptakan alam semesta, yang sejalan dengan Firman Allah yang diikrarkan 17 kali dalam sehari oleh umat muslim dalam shalat: "Sungguh shalatku, ibadahku, hidupku, dan matiku adalah milik Allah, Tuhan semesta alam."(Surah al-An'am/6: 162). (h. 155)

Kedua, Kemanusiaan sebagai landasan moral dan etika bangsa yang direfleksikan dalam Bab XA tentang Hak Asasi Manusia. Hak asasi manusia adalah klaim yang harus dipenuhi demi mempertahankan ekistensi harkat dan martabat manusia. Hal ini sejalan dengan konsep Islam tepatnya Firman Allah Surah al-Isra'/17: 70 yang memandang manusia sebagai makhluk yang 
dimuliakan oleh Allah, lebih dari makhluk-makhluk lain di alam semesta ini.

Konsep Hak-hak insan dalam Islam bisa dirujuk pada konsep al-Gazali dan segenap ahli ushul fikih dengan apa yang mereka

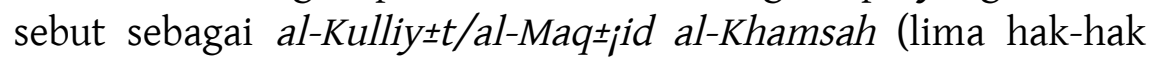
dasar universal), yaitu: 1. berkaitan dengan perlindungan jiwa dan tubuh (hifoun-nafs); 2. berkaitan dengan perlindungan akal (hifôl-'aql); 3. perlindungan atas agama/keyakinan (hifô $u d-d^{3} n$ ); 4. perlindungan atas harta benda (hifôl $u \pm 1$ ); perlindungan atas kehormatan dan keturunan (hif̧ ul-irdl wan-nasl) (h.143)

Ketiga, Persatuan sebagai landasan sosial bangsa yang dijabarkan dalam Bab XIV tentang Perekonomian Nasional dan Kesejahteraan Sosial. Persatuan dan semangat kekeluargaan untuk saling berbagi, saling bekerjasama dalam kebaikan dan ketakwaan demi mencapai tujuan mulia ini sejalan dengan Firman Allah Surah al-M $\pm \Perp_{\mathrm{idah} / 5: 2 .}$

Adalah negara sebagai penanggung jawab kepentingan umum yang memikul tanggung jawab untuk memastikan bumi, air, dan kekayaan alam dapat diakses oleh segenap warga manusia untuk kebutuhan hidupnya. Dan pemimpin Negara berikut segenap aparat publik lainnya memikul amanat untuk mendeliver anugerah Allah swt. tadi sampai ke tangan mereka sesuai kebutuhannya secara adil dan merata. (h.181-183)

Keempat, Kerakyatan sebagai acuan politik bangsa yang dijabarkan dalam Bab I tentang Bentuk dan Kedaulatan. Kerakyatan sebagai prinsip kenegaraan berarti bahwa kepentingan rakyatlah yang harus menjadi sumber inspirasi kebijakan dan langkah kekuasaan negara. Di samping itu juga suara dan kemaslahan rakyat harus menjadi acuan tertinggi bagi setiap kebijakan pemerintah dan negara.

Untuk merumuskan konsep kebijakan kenegaraan, baik program maupun organisasi, maka musyawarah untuk mencapai 
mufakat merupakan prinsip dasar dalam proses pengambilan keputusan di antara pihak (konstituen/stakeholder yang berkepentingan. Urusan orang banyak (diputuskan) dengan

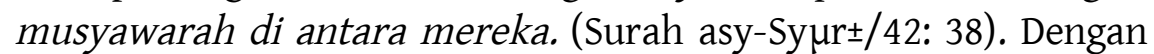
musyawarah dapat dipelihara sikap saling pengertian, saling menghargai, dan menumbuhkan tanggungjawab bersama, sehingga demokrasi yang sejati dapat terwujud dengan baik dan nyata. Di samping itu, keputusan yang diambil harus dapat dipertanggungjawabkan secara moral kepada Allah Subhanahu wa Ta'ala. (h.45-49)

Kelima, Keadilan sebagai tujuan bersama dalam bernegara. Mengelola negara dengan prinsip keadilan yang meliputi semua aspek, seperti keadilan hukum, keadilan ekonomi, dan sebagainya, yang diikuti dengan tujuan untuk kesejahteraan rakyat merupakan amanat setiap agama bagi para pemeluknya. Dalam Islam diajarkan agar pemimpin negara memperhatikan kesejahteraan rakyatnya, dan apabila menghukum mereka hendaklah

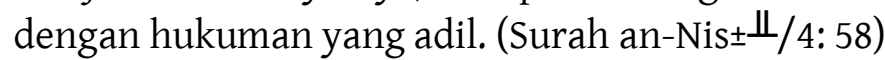

Dalam kaidah fikih Islam dinyatakan "ar-ra'iyyatu manuthun bil majlałah", artinya kepemimpinan itu mengikuti (memperhatikan) kemaslahatan rakyatnya. Artinya pemegang amanah kepemimpinan suatu negara wajib mengutamakan

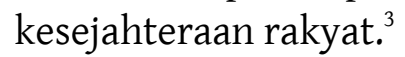

Dalam kesempatan lain Rasulullah menegaskan bahwa semua kalian adalah pemimpin, semua kalian akan dimintai pertanggungjawaban perihal yang dipimpinnya. Seorang imam adalah pemimpin, dia akan dimintai pertanggungjawaban atas rakyatnya. (Hadis Riwayat Bukhari)

Dari deskripsi syarah terhadap pembukaan UUD 1945 tersebut di atas dapat disimpulkan bahwa pengamalan ajaran

${ }^{3}$ Syamsul Hidayat, Aktualisasi Nilai-Nilai Islam dan Penguatan Ideologi Pancasila dalam Rangka Ketahanan Nasional: http://kendariekspres.com 
Islam secara konsekuen dapat memperkokoh implementasi Ideologi Pancasila dalam konteks kebangsaan. UUD 1945 dan Pancasila meskipun tidak mewakili agama tertentu, tetapi meniscayakan agar seluruh rakyat Indonesia sebagai manusia bertuhan dan beragama, dan wajib mentaati ajaran agamanya. Hal ini bermakna pula bahwa negara menjamin kemerdekaan rakyatnya untuk memilih agama sesuai dengan keyakinannya dan mendorong rakyat untuk taat menjalan ajaran agamanya, sehingga pengamalan Pancasila menjadi lebih konkret-riil.

\section{TINJAUAN KRITIS TERHADAP BUKU}

\section{Korelasi Konstitusi, Agama, dan Nilai-Nilai Islam}

Konstitusi sebagai hukum dasar merupakan kesepakatan umum (konsensus) warga negara mengenai norma dasar (grundnorm) dan aturan dasar (grund gesetze) dalam kehidupan bernegara. Kesepakatan ini utamanya menyangkut tujuan atau cita-cita bersama, the rule of the law sebagai landasan penyelenggaraan negara, serta bentuk institusi dan prosedur ketatanegaraan. ${ }^{4}$

Demikian halnya dengan Negara Kesatuan Republik Indonesia menegakkan sistem kenegaraan berdasarkan UUD 1945. Asas konstitusional UUD 1945 sebagai kaidah fundamental dan asas kerohanian negara di dalam tatanan kelembagaan dan kepemimpinan nasional yang memancarkan identitas dan integritas NKRI. Secara konstitusional Pembukaan UUD 1945 sebagai perwujudan dasar negara Pancasila dijiwai dan dilandasi dengan asas normatif theisme-religious.

Indonesia sebagai negara yang berasas Pancasila, mendekralasikan dirinya bukan negara agama yang mendasarkan pada suatu agama tertentu, dan bukan juga negara sekuler yan

${ }^{4}$ Moh. Mahfud MD, Konstitusi Negara, makalah disampaikan dalam Acara Orientasi Anggota DPR RI Fraksi PDI-P 2009-2014 pada Selasa, 8 September 2009 di Jakarta, h.2 
sama sekali tidak memperhatikan agama dan menyerahkan urusan agama kepada individu dan masyarakat. Maka, dalam konteks ini agama memberikan kerohanian yang dalam sedangkan negara menjamin kehidupan keagamaan. Artinya negara sebagai lembaga publik harus melindungi hak dan kepentingan warganya yang termuat dalam konstitusi, termasuk kebebasan beragama tanpa membeda-bedakan antara penganut yang satu dan penganut agama yang lain. ${ }^{5}$

Dengan demikian posisi agama dalam negara hukum Pancasila tidak bisa dipisahkan dengan negara dan pemerintahan. Agama menjadi satu elemen yang sangat penting dalam negara hukum Pancasila. Negara hukum Pancasila berprinsip bahwa manusia dilahirkan dalam hubungannya atau keberadaanya dengan Tuhan Yang Maha Esa. Karena itu negara tidak terbentuk karena perjanjian atau "vertrag yang dualistis" melainkan "atas berkat rahmat Allah Yang Maha Kuasa dan dengan didorong oleh keinginan luhur, supaya berkehidupan kebangsaan yang bebas...".

Pada dasarnya semua agama mengajarkan keesaaan Tuhan. Namun istilah Ketuhanan Yang Maha Esa merupakan refleksi dari falsafah dan budaya bangsa, bersumber dan terinspirasi dari nilainilai Islam yang tertulis dalam firman Allah Surah al-Baqarah/2 ayat 163: "Dan Tuhan kamu adalah Tuhan Yang Mahaesa, tidak ada Tuhan selain Dia, Yang Maha Pengasih Maha Penyayang."

Cerminan nilai-nilai Islam juga bisa dilihat dari sila-sila berikutnya, yang mana jika dicermati memang tidak ada satu pun yang berlawanan dengan nilai yang ada dalam Islam. Filsafat Pancasila memberikan kedudukan tinggi dan mulia atas potensi dan martabat manusia. Persamaan derajat, sikap saling mencintai, sikap tenggang rasa yang ada dalam sila kedua Pancasila mencerminkan nilai Islam yang terdapat pada Surah al-

\footnotetext{
${ }^{5}$ Putusan Mahkamah Konstitusi tanggal 8 Agustus 2008 No.19/PUUVI/2008 tentang “Tafsir Resmi UUD 1945” soal hubungan antara Negara dan agama dalam kerangka Negara Kesatuan Republik Indonesia. h. 24
} 
Hujurtt/49: 10 dan 13, Hal ini sesuai dengan Pancasila pada sila kedua "Kemanusiaan Yang Adil Dan Beradab". Dalam Islam tidak mengenal perbedaan status seseorang di hadapan Allah swt, yang membedakan tinggi rendahnya derajat seseorang hanyalah ketakwaannya semata,

Korelasi nilai-nilai Islam dengan konstitusi NKRI yang berlandaskan Pancasila dan UUD 1945 telah memberikan landasan dan arahan politik hukum terhadap pembangunan bidang agama (hukum agama) dengan jelas. Pada sisi lain konsep nomokrasi Islam dan konsep negara hukum Pancasila menempatkan nilainilai yang sudah terumuskan sebagai nilai standar atau ukuran nilai. ${ }^{6}$

Konsep nomokrasi Islam mendasarkan pada nilai-nilai yang terkandung pada Al Qur'an dan Sunnah sedangkan negara hukum Pancasila menjadikan nilai-nilai yang terkandung dalam Pancasila sebagai standar atau ukuran nilai. Sehingga kedua konsep ini memiliki similiaritas yang berpadu pada pengakuan adanya nilai standar yang sudah terumuskan dalam naskah tertulis. Di samping itu kedua konsep ini menempatkan manusia, Tuhan, agama dan negara dalam hubungan yang tidak dapat dipisahkan.

\section{Latar Belakang dan Urgensi Buku Syarah Konstitusi UUD 1945 dalam Perspektif Islam}

Berawal adanya kebutuhan mutlak bagaimana nilai-nilai dasar dan konsep-konsep utama dalam UUD 1945 bisa diterima sepenuh hati oleh umat Islam. Sehingga umat Islam akan bersedia memikul tanggung jawab kebangsaan dan kebernegaraannya dengan sepenuh hati. Maka Prof. Dr. Jimly Ashshiddiqie, SH. sebagai Ketua Mahkamah Konstitusi periode 2003-2008

${ }^{6}$ Konsep nomocracy berasal dari perkataan nomos dan cratos. Nomos berarti norma, sedangkan cratos adalah kekuasaan. Karena itu, istilah nomokratis itu berkaitan erat dengan ide kedaulatan hokum atau prinsip hokum sebagai kekuasaan tertinggi. (Lihat: Daniel S.Lev, Hukum dan Politik di Indonesia: Kesinambungan dan Perubahan, Jakarta: LP3S, 1990, h. 416) 
memprakarsai adanya telaah komprehensif mengenai konstitusi Indonesia dalam perspektif Islam yang diharapkan mampu untuk menjelaskan keberadaan Islam dalam sistem konstitusionalise di Indonesia. (h. xiv)

Buku setebal 236 halaman sangat penting untuk meretas benang keraguan dan sikap setengah hati umat Islam yang di sana-sini masih kerap muncul dalam hidup berbangsa dan bernegara.Selain itu, buku ini diharapkan pula dapat menjadi rujukan sekaligus penengah terhadap sekelumit kontroversi hukum di Indonesia, yaitu sebagian kalangan menafsirkan hukum di Indonesia merupakan suatu hukum sekuler, dan di lain pihak terdapat tuntutan kalangan untuk merealisasikan islamisasi hukum di Indonesia.

Buku ini secara substansi memberikan syarah menurut perspektif Islam terhadap pointers penting tiap pasal/bab dari konstitusi UUD 1945. Syarah yang dituliskan lebih bersifat istidlal/hasyiyah menjabarkan dan menunjukkan secara global dan deskriptif dalil naqliyah/dalil aqliyah menurut perspektif Islam terhadap naskah konstitusi. Buku ini mencirikan kekhususan tema besar tentang hubungan negara dan agama, tepatnya Indonesia dengan Islam, sehingga objek yang dituju adalah umat Islam. Buku ini bergambar palu pada cover dan berlatar belakang bewarna hitam menampilkan pesan yang tersirat dari lembaga negara berkaitan dengan hukum dan konstitusi, yaitu Mahkamah Konstitusi.

Mahkamah Konstitusi selaku lembaga negara yang berfungsi sebagai penafsir final konstitusi UUD 1945 berharap kehadiran buku Syarah Konstitusi UUD 1945 dalam Perspektif Islam dapat mendukung penyebarluasan informasi tentang UUD 1945 dan dapat mewujudkan budaya sadar berkonstitusi. Ketua Mahkamah Konstitusi Mahfud MD. dalam pengantarnya berharap umat Islam yang dikenal kental karakter keagamaannya akan lebih mudah memahami teks konstitusi melalui perantara teks ayat sucinya 
sehingga lebih mudah untuk mewujudkan budaya sadar konstitusi di kalangan umat muslim Indonesia. (h. iv)

Prof. Dr. Jimly AshShiddiqie, SH. sebagai Ketua Mahkamah Konstitusi periode 2003-2008 yang memprakarsai lahirnya buku ini, sebelumnya telah menuliskan catatan kaki pada bukunya yang berjudul Konsolidasi Naskah UUD 1945. Catatan kaki ditulis pada setiap rumusan pasal dan ayat sebagai tambahan keterangan, penjelasan ataupun kritik terhadap rumusan pasal dan ayat-ayat UUD 1945 tersebut. Namun Jimly AshShiddiqie ingin konsolidasi naskah UUD 1945 dijabarkan dan disyarahkan menurut perspektif agama Islam. Untuk merealisasikan hal itu Masdar F. Mas'udi pun mengusulkan untuk menyusun dan menerbitkan buku Syarah Konsititusi UUD 1945 dalam Perspektif Islam. Buku itu pun tersusun dengan pola penulisan syarah senada tetapi tidak sama dengan buku berjudul Konsolidasi Naskah UUD 1945 karya Jimly Ashshiddiqie. (h.xxiv)

Dengan demikian, teks konstitusi diposisikan untuk semakin meneguhkan semangat kebangsaan. Dan teks ayat suci yang terkait dengan konstitusi untuk memperkuat komitmen umat Islam Indonesia selaku warga negara untuk taat kepada konstitusi sebagai hukum tertinggi dalam penyelenggaraan negara. Titik temu ayat konstitusi dan ayat agama seperti terjabarkan dalam buku ini sebenarnya bertitik tolak pada ajaran bersama bahwa bernegara itu sama pentingnya dengan beragama. Memperkuat negara sama pentingnya dengan memperkuat agama. Di samping itu juga toleransi saudara sebangsa itu tidak jauh berbeda dari toleransi dengan sesama dan antarpemeluk agama yang dianut masyarakat Indonesia.

Secara tidak langsung Buku Syarah Konstitusi UUD 1945 telah menyanggah buku tentang Kuasa Negara atas Agama Politik Pengakuan, Diskursus "Agama Resmi" dan Diskriminasi Hak Sipil, yang dalam bab pendahuluan menyatakan bahwa kebijakan politisasi negara atas agama menurut penulisnya (Tedi Kholiludin) 
masih buram, dan menyisakan permasalahan kemanusiaan yang cukup besar untuk diselesaikan. Buku ini hendak menggambarkan implementasi politik pengakuan negara terhadap agama, implikasi dari pengakuan, dan dampak yang muncul dari proses tersebut, baik secara sosial maupun politik. ${ }^{7}$

Buku Syarah Konstitusi UUD 1945 menunjukkan bahwa konstitusi UUD 1945 tepatnya pasal 29 ayat 1 dan 2 telah mengatur tentang kehidupan beragama dimana setiap penganut agama dan kepercayaan dijamin haknya dalam UUD 1945 untuk beribadah. Dengan demikian konstitusi mengakui akan eksistensi dan mengamanatkan bagi seluruh warga Negara untuk menjalankan kehidupan beragamanya. Hal ini juga mengisyaratkan bahwa Indonesia adalah rumah bagi semua agama dan keyakinan, tanpa harus terjebak pada formalisasi agama dalam mengarungi kehidupan berbangsa dan bernegara.

Kiai Hasyim Muzadi dalam sebuah seminar memperingati Harlah NU ke-88 menyatakan bahwa di Indonesia, agama dijadikan sebagai roh atau substansi undang-undang. Makanya didapati hukum perkawinan yang menjadi hukum positif dan kemudian kompilasi hukum Islam dan UU pornografi yang dijadikan sebagai rujukan di dalam penetapan hukum yang berkaitan dengan masyarakat Islam. Jadi, agama tidak diformalkan menjadi hukum positif, akan tetapi agama dijadikan sebagai roh dan etika yang mendasari hukum positif. ${ }^{8}$

Dengan demikian, tidak ada salahnya perumusan perundang-undangan, aturan hukum, baik dalam cakupan nasional maupun lokal daerah menyerap nilai-nilai ajaran agama yang ada di Indonesia dengan atau tanpa menyebut identitas suatu agama. Halhal yang berkaitan dengan agama tertentu, seperti UU

7 Tedi Kholiludin, Kuasa Negara atas Agama Politik Pengakuan, Diskursus" Agama Resmi" dan Diskriminasi Hak Sipil, Rasail Media Group, Semarang, Mei 2009, h. 17

${ }^{8}$ Hasyim Muzadi, Seminar memperingati Harlah NU ke-88 di Jawa Timur pada tanggal 22 Februari 2011 
Perkawinan, UU Peradilan Agama, UU Zakat, UU Perbankan Syariah dan sejenisnya yang berlaku khusus untuk umat Islam hendaknya tidak dilihat sebagai bentuk diskriminasi, dengan alasan eksklusivitas. Sebab secara historis hukum Islam dengan segenap pola legislasinya telah teruji, baik eksistensinya maupun efektivitasnya. Selain itu juga negara telah menjadikan agama sebagai etika dan moralitas di dalam penyelenggaraan negara, yang semuanya telah dipayungi oleh paradigma nasional, yaitu Pancasila dan UUD RI 1945.

\section{PENUTUP}

Buku ini menarik dan up to date terhadap wacana dan problematika hukum dan agama. Syarah pada buku ini sifatnya sebagai petunjuk/guide terhadap konsolidasi naskah UUD 1945 secara global dan deskriptif menurut perspektif Islam. Sehingga secara tidak langsung buku ini dapat meretas benang keraguan dan sikap setengah hati umat Islam terhadap konstitusi UUD 1945 dalam hidup berbangsa dan bernegara.

Buku ini menunjukkan bahwa kandungan konstitusi UUD 1945 adalah islami dan sejalan dengan ajaran Islam. Indonesia dengan dengan dasar Pancasila dan UUD 1945 adalah negara yang islami, tapi bukan negara Islam. Negara Islami adalah negara yang secara resmi tidak menggunakan nama dan simbol-simbol Islam tetapi substansinya mengandung nilai-nilai substantif ajaran Islam.

Buku ini lebih bersifat katalisator atau mediasi antara lembaga negara dengan umat Islam dengan mensyarahkan pointers konstitusi UUD 1945 menurut pandangan Islam. Metode yang disampaikan bersifat dakwah dan singkat tanpa memunculkan gagasan yang bersifat argumentatif dan kritis dalam bentuk footnote dan daftar pustaka. 


\section{DAFTAR PUSTAKA}

Jimly Asshiddiqie, Membangun Budaya Sadar Berkonstitusi, Makalah diseminarkan di DPP Partai Golkar, Jakarta: 8 Juli 2008

Al Halaj Muhyiddin, Pancasila dan Pembukaan UUD 1945 Tidak Bisa Diubah dan Tidak Boleh Diubah, al-KautsarDhibradotkom, 2010

Syamsul Hidayat, Aktualisasi Nilai-Nilai Islam dan Penguatan Ideologi Pancasila dalam Rangka Ketahanan Nasional: http://kendariekspres.com

Moh. Mahfud MD, Konstitusi Negara, makalah disampaikan dalam Acara Orientasi Anggota DPR RI Fraksi PDI-P 2009-2014 pada Selasa, 8 September 2009 di Jakarta, h.2

Putusan Mahkamah Konstitusi tanggal 8 Agustus 2008 No.19/PUU-VI/2008 tentang “Tafsir Resmi UUD 1945” soal hubungan antara Negara dan agama dalam kerangka Negara Kesatuan Republik Indonesia. h. 24

Konsep nomocracy berasal dari perkataan nomos dan cratos. Nomos berarti norma, sedangkan cratos adalah kekuasaan. Karena itu, istilah nomokratis itu berkaitan erat dengan ide kedaulatan hokum atau prinsip hokum sebagai kekuasaan tertinggi. (Lihat: Daniel S.Lev, Hukum dan Politik di Indonesia: Kesinambungan dan Perubahan, Jakarta: LP3S, 1990, h. 416)

Tedi Kholiludin, Kuasa Negara atas Agama Politik Pengakuan, Diskursus" Agama Resmi" dan Diskriminasi Hak Sipil, Rasail Media Group, Semarang, Mei 2009, h. 17

Hasyim Muzadi, Seminar memperingati Harlah NU ke-88 di Jawa Timur pada tanggal 22 Februari 2011 